Pediat. Res. 4: 14-24 (1970)

Birth weight infants postnatal malnutrition bromide space metabolism premature infants growth retardation newborn water

\title{
Bromide Space Studies in Infants of Low Birth Weight
}

\author{
George CAssady ${ }^{[64]}$ \\ Perinatal Research Laboratory, Department of Pediatrics, University of Alabama Medical Center, \\ Birmingham, Alabama, USA
}

\begin{abstract}
Extract
The present study reports measurements of the corrected bromide space (CBS) in 74 neonates delivered vaginally and studied within $24 \mathrm{~h}$ of birth. The results in 37 normally grown (NG) infants ranging in birth weight from 960 to 3,540 g with gestational intervals of 27-43 weeks are contrasted with findings in 37 intrauterine growth-retarded infants (IGR) ranging from 1,000 to $2,460 \mathrm{~g}$ in birth weight with gestational intervals of 35-44 weeks.

Although a direct relation exists between CBS (liters) and a variety of variables of fetal maturity in both NG and IGR infants, the CBS in both groups would appear best related to birth weight. The corrected bromide space of the IGR was virtually identical with that of their weight peers, there being no significant difference in the regression for CBS versus birth weight in the two groups. Log-log plot of this relation yields a correlation coefficient $(r)$ of 0.98 , and may be expressed as: $\log$ CBS (liters) $=0.92 \times \log \mathrm{wt}(\mathrm{kg})-0.371$

Closer inspection of this relation revealed that an unequal distribution, with preponderance of values below the regression line at higher birth weights, was apparent. This 'tail off' suggested a curvilinear relation of CBS with increasing birth weight, and was even more apparent when the CBS data were expressed as percentage of bcdy weight $(\mathrm{ml} / \mathrm{kg})$. The mean $\mathrm{CBS} / \mathrm{kg}$ in NG prematures $(424 \pm$ sE $7.5 \mathrm{ml} / \mathrm{kg})$ was clearly higher $(P<0.001)$ than in mature study infants $(376 \pm \mathrm{sE} 8.4 \mathrm{ml} / \mathrm{kg})$. Likewise, the average CBS $/ \mathrm{kg}$ in the mature IGR $(419 \pm \mathrm{SE} 11.3 \mathrm{ml} / \mathrm{kg})$ was significantly higher $(P<0.025)$ than the mean for the NG infants $(376 \pm \mathrm{sE} 8.4 \mathrm{ml} / \mathrm{kg})$. Comparison of data from NG and IGR infants revealed that 3 of 10 premature infants and 10 of 27 mature IGR infants have a CBS $/ \mathrm{kg}$ more than $2 \mathrm{sD}$ above the mean in NG infants; a CBS in excess of $476 \mathrm{ml} / \mathrm{kg}$ was observed in 11 study infants, all but 1 of whom were IGR.
\end{abstract}

\section{Speculation}

Characteristically, expansion of body water compartments accompanies postnatal malnutrition. In intrauterine growth retardation, similar changes in body fluid compartments suggest an etiologic role for 'fetal malnutrition' in the disorder. 


\section{Introduction}

One of every three neonates of low birth weight represents the sequelae of impaired intrauterine growth $[28,47,48]$. As a result of observations made during the past decade, clinical [46-48,55], chemical [7, 14, 44], morphometric [42], metabolic [50], neurologic [17], and developmental [18, 55] differences clearly separate these neonates from their weight peers. Clinical observations $[14,18,44,46,47,55]$ suggesting poor fetal nutrition have led to the term 'fetal malnutrition' and certain of these findings (dry cracked skin, poor subcutaneous turgor, and diminished postnatal weight loss), as well as an elevated metabolic rate per kilogram of body weight [50], have been interpreted as suggesting a contracted, hyperosmolal extracellular space in the intrauterine growth-retarded (IGR) neonate [47, 49]. Clinical assumptions of fetal malnutrition with dehydration, hypovolemia, and hyperosmolality are, however, mutually contradictory. Abundant data concerning malnutrition in human infants $[1,4,13,16,25,27,33,37,38,40,45,52,56]$ and in experimental animals $[19,36,59]$ provide conclusive evidence for an expansion of fluid compartments (when expressed as percentage of body weight) in postnatal protein-calorie malnutrition, the extent of which is directly related to the severity of malnutrition $[30,34]$.

With these discrepancies in mind, it has been our purpose to study certain variables of body composition in intrauterine growth-retarded (IGR) neonates. This report presents observations concerning the extracellular compartment as estimated by 3 -h bromide dilution studies in 74 neonates that were delivered vaginally and evaluated within $24 \mathrm{~h}$ of birth.

\section{Materials and Methods}

Catheterization of the umbilical vein, injection of $2 \% \mathrm{NaBr}$, and quadruplicate determinations of plasma bromide $3 \mathrm{~h}$ postinjection were carried out in all study infants. The quantity of bromide injected was determined gravimetrically and averaged $74 \mathrm{mg} / \mathrm{kg}$ (range: $36-93 \mathrm{mg} / \mathrm{kg}$ ) ; concentrations of plasma bromide ranged from 1.0 to $2.5 \mathrm{~mm} / \mathrm{liter}(8-20 \mathrm{mg} / 100 \mathrm{ml})$.

Plasma bromide was estimated using a modification of the colorimetric gold bromide technique [61]. Spectral scanning revealed maximum absorption at $350 \mathrm{~m} \mu$ and all optical density readings were made at this wave length. A variable rate of color development was observed and serial readings, therefore, were made immediately, beginning with addition of the gold chloride and continuing until diminishing absorption was observed. Coefficient of variation for this technique averaged $5.3 \%$.
The bromide space was calculated from the following formula :

bromide space $(\mathrm{mI})=$

$\frac{\text { bromide injected }(\mathrm{mg})}{3-\mathrm{h} \text { plasma bromide conc }(\mathrm{mg} / \mathrm{ml})} \times \frac{0.90}{0.95 \times 0.934}$

Correction for Donnan factor was arbitrary (0.95) but correction for plasma water (0.934) was based on the results obtained in this laboratory by drying to constant weight plasma samples from 12 study infants of low birth weight. A final 10\% correction for estimated intracellular bromide (0.90) was used as suggested by the data from GHEEK et al. [8-11]. Loss of bromide in the urine was assumed to be negligible on the basis of stable bromide concentrations in serum from 3 to $15 \mathrm{~h}$ after injection as observed by FINK and GHeEk [21] and confirmed in this laboratory. The age halfway through the study (90 min after bromide injection) was considered study age.

All studies were carried out at ambient temperatures between 31.7 and $34.4^{\circ}$. The cord was clamped after the first breath; therefore, study infants received a placental transfusion [7]. Menstrual history was elicited carefully by personal interview at the same time that appropriate informed consent for thestudy was obtained. Gestational interval was calculated from day 1 of the last normal menstrual period and expressed to the nearest week. Intrauterine growth was estimated by comparison of the observed birth weight of the infant with the average expected weight for gestational age from both the data of GRUENWALD [29] and from our institution [unpublished data]. Infants with birth weights between GRUENWALD's 10th and 90th percentiles were considered to have grown normally; infants with birth weights more than $2 \mathrm{sD}$ below our expected mean for gestational age, sex, and race were considered to exhibit severe growth retardation. As the GRUENWALD growth data was quite similar to our own, all but two of the severely growth retarded study infants were more than 2 sD below the mean of GRUENWALD's weight data [29]. Those infants whose birth weight fell below Gruenwald's 10th percentile but above our -2 SD limit were considered undergrown or exhibiting moderate growth retardation.

Intravenous fluid therapy was required by clinical circumstances in 16 study infants (9 NG and 7 IGR) prior to or during the study period. Parenteral fluid was more commonly required in true prematures $(8 / 24)$ than in mature (1/13) or IGR infants $(7 / 37)$. An average of $26 \mathrm{ml}$ isosmolar fluid (range 5-85 ml) was provided in these infants. Four study infants (2 NG, 2 IGR) were fed a total of $30-90 \mathrm{ml}$ of $5 \%$ dextrose prior to the study. Corrected bromide space was similar in those 20 infants who received oral or intravenous fluids $(420 \pm 12.6 \mathrm{ml} / \mathrm{kg})$ to that observed in 
the 54 study infants who received neither liquids nor nourishment $(417 \pm 7.6 \mathrm{ml} / \mathrm{kg})$.

Surface area was calculated from the formula of Boyd [3] :

$$
\mathrm{SA}=3.207\left(w t^{0.7285-0.0188 \log w t}\right)\left(h t^{0.3}\right)
$$

\section{Results}

\section{Clinical Characteristics}

Race, sex, birth weights, gestational intervals, and physical characteristics of the 74 infants in the study have been summarized in table I. The birth weights of 37 neonates were appropriate for their gestational age. Twenty-four of these normally grown (NG) infants were premature babies: average gestational interval was 32 weeks, and mean birth weight was $1,855 \mathrm{~g}$. Intrauterine growth retardation (IGR) was present in 37 infants. These infants were predominantly mature (mean gestation, 38 weeks) but in birth weight and other physical characteristics the IGR group was almost identical with the NG premature group. Birth weight of the IGR infants averaged $65 \%$ of expected weight and $91 \%$ of expected length.

Birth weights of the 74 infants in the study have been plotted with reference to their gestational interval (fig. 1). The expected lower range of normal intrauterine growth, as estimated by GRUENWALD, has been superimposed on this scatterplot.

\section{Normally Grown Neonates}

Table II provides details concerning the relation between the corrected bromide space (CBS), in liters, and a variety of variables of fetal maturity in the 37 NG neonates. A direct relation between CBS and these variables was both apparent and expected. The relation of physical variables other than weight, the use of calculated rather than measurable variables, surface area and gestational age, and the construction of multiple or complex regression analyses have all been considered in the presentation of these data. As summarized briefly in table II, the corrected bromide space appears best related to birth weight. Although estimates of the extracellular space within $24 \mathrm{~h}$ of birth are scant in the literature, comparable measurements using bromide and thiocyanate dilution methods are available from 24 mature neonates $[21,26]$ and 3 infants of low birth weight [21]. These results, along with results of carcass analyses in 19 stillbirths $[4,5$, $20,32]$, are combined with our data and illustrated in scattergram form in figure 2 . The regression equation and correlation coefficient for the combined data were virtually identical with the figures calculated from our data alone, a finding that was particularly striking in view of the varying techniques from different laboratories and the inclusion of both in vivo and stillbirth studies in the combined data. The concept of relative growth (allometry), initially introduced by HuXLEY [31] and adopted by WEIL [58], suggests that log-log

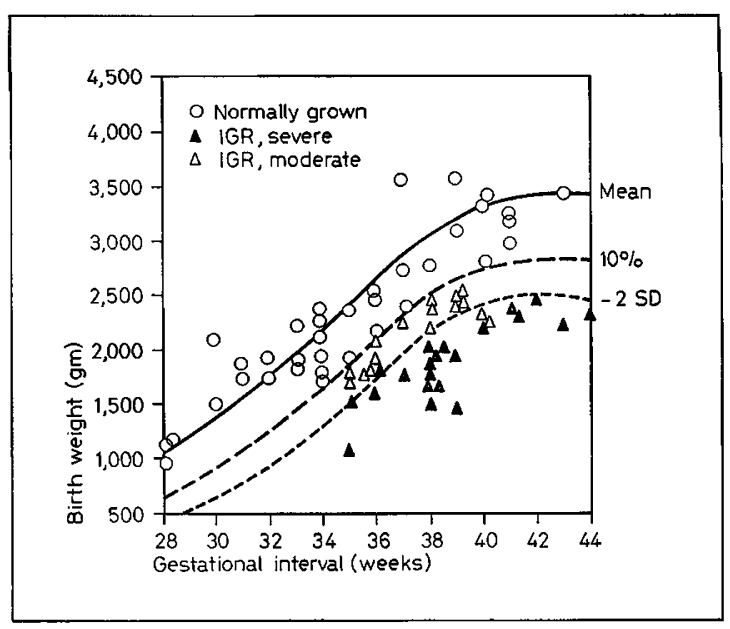

Fig. 1. Relation between birth weight and gestational interval in 74 study infants; individual values have been scatterplotted over the expected lower range of normal intrauterine growth as estimated by GRUENWALD [29].

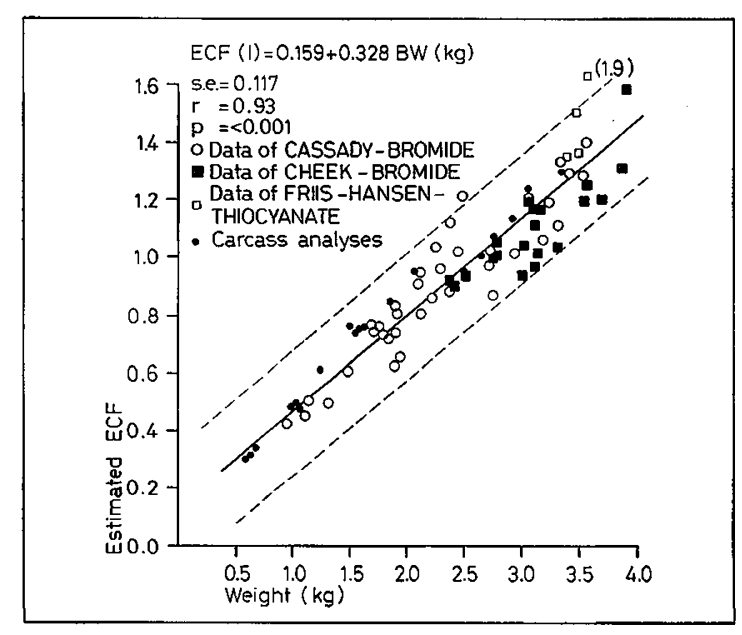

Fig.2. Relation between the estimated total volume of extracellular fluid (ECF, in liters) and birth weight (kilograms); individual data from neonates presumed to have achieved normal growth and studied within $24 \mathrm{~h}$ of birth, and from carcass analyses (see text) are scatterplotted with the data from the present study; the regression equation for the total relation (assuming linearity) was superimposed as the solid line (broken line indicates limits of $\pm 2 \mathrm{sE}$ ). 
plotting of these variables may be a more appropriate method of handling these data. Regression expression for this relation is:

$\log \mathrm{CBS}$ (liter) $=0.912 \times \log$ birth wt $(\mathrm{kg})-0.371$ with a correlation coefficient of 0.98 and sy. $x$ of 0.025 .

Careful inspection of figure 2 reveals unequal distribution of individual values above and below the re- gression line at higher weights. This 'tail-off', in combination with $r$ values of less than 1 for these relationships, suggests a curvilinear or changing relation between total extracellular volume and birth weight. For further analysis of these observations, and also to present these data in such a manner as to be comparable to figures from other investigators, GBS has been

Table I. Glinical characteristics of study infants

\begin{tabular}{|c|c|c|c|c|c|c|c|}
\hline Infant study group & $\begin{array}{l}\text { No. of } \\
\text { infants }\end{array}$ & $\begin{array}{l}\text { Sex, } \\
\mathrm{M} / \mathrm{F}\end{array}$ & $\begin{array}{l}\text { Race, } \\
\text { N/W }\end{array}$ & $\begin{array}{c}\text { Mean } \\
\text { gestational } \\
\text { interval, } \\
\text { wk }\end{array}$ & $\begin{array}{c}\text { Mean birth wt, } \\
\mathrm{g}\end{array}$ & $\begin{array}{c}\text { Mean } \\
\text { crown-heel } \\
\text { length, } \\
\text { cm }\end{array}$ & $\begin{array}{c}\text { Mean } \\
\text { occipito- } \\
\text { frontal head } \\
\text { circum- } \\
\text { ference, } \mathrm{cm}\end{array}$ \\
\hline \multicolumn{8}{|l|}{ Normally grown } \\
\hline $27-32 \mathrm{wk}$ & 10 & $5 / 5$ & $10 / 0$ & 30 & $\begin{array}{c}1,525 \\
(960-2,100)^{\mathbf{x}}\end{array}$ & $\begin{array}{c}40 \\
(36-45)^{1}\end{array}$ & $\begin{array}{c}28 \\
(25-31)^{1}\end{array}$ \\
\hline $33-36 \mathrm{wk}$ & 14 & $6 / 8$ & $12 / 2$ & 34 & $\begin{array}{c}2,090 \\
(1,740-2,480)\end{array}$ & $\begin{array}{c}46 \\
(42-48)\end{array}$ & $\begin{array}{c}32 \\
(28-34)\end{array}$ \\
\hline $37-43 \mathrm{wk}$ & $12^{2}$ & $5 / 7$ & $10 / 2$ & 40 & $\begin{array}{c}3,145 \\
(2,700-3,540)\end{array}$ & $\begin{array}{c}50 \\
(47-53)\end{array}$ & $\begin{array}{c}34 \\
(32-36)\end{array}$ \\
\hline \multicolumn{8}{|l|}{ Intrauterine growth retarded } \\
\hline Total group & 37 & $14 / 23$ & $28 / 9$ & $\begin{array}{c}38 \\
(35-44)^{1}\end{array}$ & $\begin{array}{c}1,965 \\
(1,000-2,460)\end{array}$ & $\begin{array}{c}44 \\
(35-48)\end{array}$ & $\begin{array}{c}30 \\
(25-34)\end{array}$ \\
\hline \multicolumn{8}{|l|}{ Maturity } \\
\hline $35-36$ wk & 10 & $4 / 6$ & $9 / 1$ & 36 & $\begin{array}{c}1,660 \\
(1,000-2,020)\end{array}$ & $\begin{array}{c}43 \\
(35-48)\end{array}$ & $\begin{array}{c}29 \\
(25-31)\end{array}$ \\
\hline $37-44$ wk & 27 & $10 / 17$ & $19 / 8$ & 39 & $\begin{array}{c}2,080 \\
(1,420-2,460)\end{array}$ & $\begin{array}{c}45 \\
(39-48)\end{array}$ & $\begin{array}{c}31 \\
(27-34)\end{array}$ \\
\hline \multicolumn{8}{|l|}{ Severity } \\
\hline Moderate & 16 & $4 / 12$ & $15 / 1$ & $\begin{array}{c}38 \\
(35-40)\end{array}$ & $\begin{array}{c}2,130 \\
(1,680-2,460)\end{array}$ & $\begin{array}{c}46 \\
(42-48)\end{array}$ & $\begin{array}{c}31 \\
(28-34)\end{array}$ \\
\hline Severe & 21 & $10 / 11$ & $13 / 8$ & $\begin{array}{c}39 \\
(35-44)\end{array}$ & $\begin{array}{c}1,845 \\
(1,000-2,380)\end{array}$ & $\begin{array}{c}43 \\
(35-48)\end{array}$ & $\begin{array}{c}30 \\
(25-33)\end{array}$ \\
\hline Length $<90 \% \exp$ & 10 & $3 / 7$ & $5 / 5$ & $\begin{array}{c}38 \\
(35-43)\end{array}$ & $\begin{array}{c}1,735 \\
(1,000-2,460)\end{array}$ & $\begin{array}{c}41.5 \\
(39-44)\end{array}$ & $\begin{array}{c}30 \\
(25-33)\end{array}$ \\
\hline Length $>90 \% \exp$ & 17 & $5 / 12$ & $14 / 3$ & $\begin{array}{c}38 \\
(35-41)\end{array}$ & $\begin{array}{c}2,120 \\
(1,680-2,420)\end{array}$ & $\begin{array}{c}46.5 \\
(43-48)\end{array}$ & $\begin{array}{c}31 \\
(27-34)\end{array}$ \\
\hline \multicolumn{8}{|l|}{ Etiology } \\
\hline IgM elevated & 3 & $2 / 1$ & $2 / 1$ & $\begin{array}{c}36 \\
(35-36)\end{array}$ & $\begin{array}{c}1,700 \\
(1,560-1,780)\end{array}$ & $\begin{array}{c}42 \\
(42)\end{array}$ & $\begin{array}{c}30 \\
(28-31)\end{array}$ \\
\hline Twinning & 7 & $2 / 5$ & $3 / 4$ & $\begin{array}{c}38 \\
(36-39)\end{array}$ & $\begin{array}{c}1,785 \\
(1,420-2,460)\end{array}$ & $\begin{array}{c}43 \\
(40-45)\end{array}$ & $\begin{array}{c}32 \\
(30-33)\end{array}$ \\
\hline Renovascular & 14 & $4 / 10$ & $11 / 3$ & $\begin{array}{c}38 \\
(35-43)\end{array}$ & $\begin{array}{c}1,835 \\
(1,000-2,380)\end{array}$ & $\begin{array}{c}44 \\
(35-48)\end{array}$ & $\begin{array}{c}30 \\
(25-34)\end{array}$ \\
\hline Placental abnormalities & 5 & $2 / 3$ & $2 / 3$ & $\begin{array}{c}40 \\
(36-43)\end{array}$ & $\begin{array}{c}2,070 \\
(1,700-2,380)\end{array}$ & $\begin{array}{c}43 \\
(42-43)\end{array}$ & $\begin{array}{c}32 \\
(31-32)\end{array}$ \\
\hline
\end{tabular}

${ }^{1}$ Numbers in parentheses indicate range of values.

${ }^{2}$ Excludes one female baby, 2,290 g, 37 weeks old, Negro. 
Table II. Relation between study variables of normal infants ${ }^{1}$

\begin{tabular}{|c|c|c|c|c|c|}
\hline Dependent variable & Intercept + & Slope & $\begin{array}{l}\text { Independent } \\
\text { variable }\end{array}$ & $\begin{array}{l}\text { Correlation } \\
\text { coefficient }\end{array}$ & sy.x \\
\hline CBS (1) & -0.884 & +0.051 & Gestational age, wk & 0.83 & 0.14 \\
\hline GBS (1) & -0.136 & +0.335 & Birth wt, kg & 0.93 & 0.10 \\
\hline GBS (1) & -1.735 & +0.058 & Length, $\mathrm{cm}$ & 0.90 & 0.12 \\
\hline GBS (1) & -0.231 & +6.702 & Surface area, $\mathrm{m}^{2}$ & 0.94 & 0.09 \\
\hline CBS (1) & -1.725 & +0.084 & $\begin{array}{l}\text { Head circumference, } \\
\mathrm{cm}\end{array}$ & e, 0.86 & 0.14 \\
\hline CBS (1) & +0.270 & $\begin{array}{l}-5.882 \\
+0.366\end{array}$ & $\begin{array}{l}\text { Gestational age }+ \\
\text { birth wt }\end{array}$ & 0.93 & 0.10 \\
\hline CBS (1)-gestational effect ${ }^{2}$ & -0.142 & +0.062 & Birth wt & 0.31 & 0.14 \\
\hline GBS (1)-wt effect ${ }^{2}$ & +0.036 & -1.060 & Gestational age & -0.05 & 0.09 \\
\hline CBS (1) & -0.447 & $\begin{array}{r}+15.689 \\
+0.728 \\
-1.012\end{array}$ & $\begin{array}{l}\text { Gestational age }+ \\
\text { birth } w t+ \\
\text { (gestation } \times w t \text { ) }\end{array}$ & 0.94 & 0.09 \\
\hline
\end{tabular}

' Regression analyses and multiple regression analysis of relationships between CBS (corrected bromide space) and various variables of maturity in normally grown study infants.

${ }^{2}$ GBS-(slope $\times$ independent variable)-intercept for effect removed. (See Ostel, B.: Statistics in research, 2nd ed. [Iowa State University Press, Ames, Iowa 1963].)

Table III. Group comparisons ${ }^{1}$

\begin{tabular}{llcc}
\hline Group comparisons of study infants & $\begin{array}{c}\text { No. of } \\
\text { infants }\end{array}$ & $\begin{array}{c}\text { Corrected bromide } \\
\text { space, ml/kg }\end{array}$ & $P$ \\
\hline Normally grown, mature, 37-43 wk & 12 & $376 \pm 8.4^{2}$ & $<0.001$ \\
$\quad$ vs. normal grown, premature & 24 & $424 \pm 7.5$ & $<0.001$ \\
vs. IGR ${ }^{3}$, all & 37 & $427 \pm 11.4$ & $<0.025$ \\
vs. IGR mature, 38-44 wk & 27 & $419 \pm 11.3$ & $<0.005$ \\
vs. IGR mature, severe & 17 & $435 \pm 13.1$ & $\mathrm{~ns}^{4}$ \\
vs. IGR mature, moderate & 10 & $391 \pm 17.0$ & $\mathrm{~ns}^{4}$ \\
Normally grown, premature, 33-36 wk & 14 & $423 \pm 11.8$ & $\mathrm{~ns}$ \\
vs. IGR premature, 35-36 wk & 10 & $448 \pm 28.3$ & $\mathrm{~ns}$ \\
IGR, severe & 21 & $437 \pm 13.5$ & $413 \pm 19.0$ \\
$\quad$ vs. IGR, moderate & 16 & $401 \pm 18.6$ & $<0.005$ \\
IGR, unknown etiology & 11 & $438 \pm 13.6$ & \\
$\quad$ vs. IGR, presumably known etiology & 26 & $368 \pm 20.9$ & \\
IGR, length <90\% expected & 10 & $395 \pm 13.5$ & \\
$\quad$ vs. IGR, length 90-100\% expected & 16 & & \\
\hline
\end{tabular}

1 Statistical analyses of certain apparent differences in grouped averages for corrected bromide space. (Further description of study infants in these groups in table I and in text.)

2 Mean \pm 1 SE.

${ }^{3}$ IGR = intrauterine growth retarded.

${ }^{4} \mathrm{~ns}=$ not significant. 
expressed as percentage of body weight (or $\mathrm{ml} / \mathrm{kg}$ ), and grouped averages in clinically differing groups of study infants are compared in table III. The average corrected bromide space is clearly higher (almost 50 $\mathrm{ml} / \mathrm{kg}$ ) in NG premature infants (424 with $\mathrm{se} \pm 7.5$ ) than in the mature infants ( 376 with SE \pm 8.4 ); all but one of the mature infants have values less than the mean for the premature infants.

\section{Intrauterine Growth-retarded Neonates}

Table IV provides details concerning the relation between the corrected bromide space (liter) and a variety of variables of fetal maturity in the 37 IGR infants. As with infants of normal growth, this relation appears best expressed in terms of birth weight. There was no significant difference in the relation between birth weight and CBS in NG and IGR infants ( $F=$ 0.218 ). This is graphically shown in figure 3 where individual values for the IGR infants are overplotted on the linear regression $\pm 2 \mathrm{sE}$ for the values from $\mathrm{NG}$ infants. Symmetrical distribution of the values about the mean, and inclusion of all but two within the $\pm 2 \mathrm{SE}$ range for $\mathrm{NG}$ neonates, indicates that the corrected bromide space of the IGR infants was virtually identical with that of their weight peers.

The data are expressed as percentage of body weight $(\mathrm{ml} / \mathrm{kg})$ in figure 4 and table III. In figure 4 , the CBS of 10 'premature' IGR infants (33-36 weeks gestation) and 27 mature IGR infants (37-43 weeks gestation) were superimposed individually on the grouped averages \pm 1 sD for NG neonates. The higher values in many of the IGR infants were clearly apparent. In 3 of the 10 'premature' IGR infants (30\%), and in 10 of the 27 mature IGR infants (37\%), corrected bromide spaces were observed of more than 2 SD above the mean for NG infants. The average corrected bromide

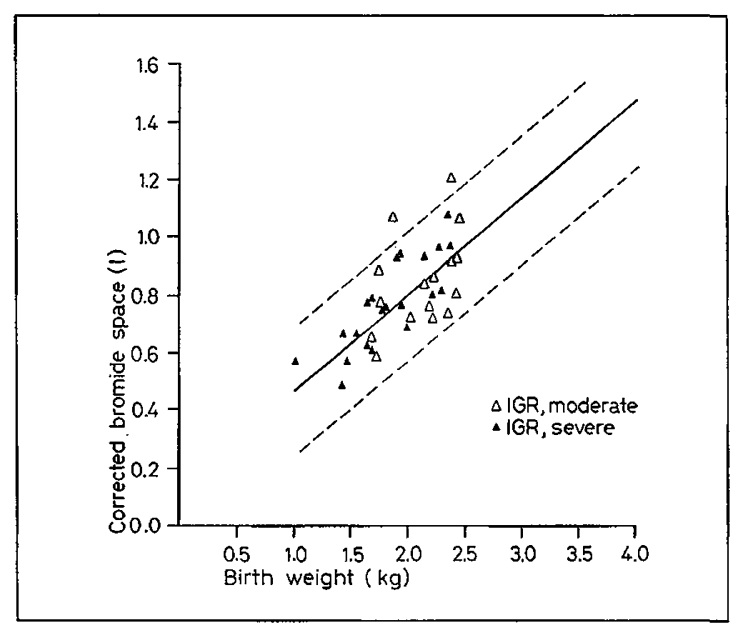

Fig. 3. Relation between total corrected bromide space (liters) and birth weight (kilograms) in 37 intrauterine growth-retarded (IGR) study infants; individual results from IGR infants are superimposed on the mean \pm 2 SE regression lines of the normally grown (NG) infants from this study. (See fig. 2.)

Table IV. Relation between study variables in growth-retarded infants ${ }^{1}$

\begin{tabular}{|c|c|c|c|c|c|c|c|}
\hline Dependent variable & $=$ & Intercept & + Slope & $\times$ & Independent variable & $\begin{array}{c}\text { Correlation } \\
\text { coefficient }\end{array}$ & sy.x \\
\hline CBS (1) & & -0.335 & +0.030 & & Gestational age, wk & 0.41 & 0.15 \\
\hline CBS (1) & & +0.184 & +0.319 & & Birth wt, kg & 0.70 & 0.12 \\
\hline CBS (1) & & +0.057 & +16.947 & & Length, $\mathrm{cm}$ & 0.37 & 0.14 \\
\hline CBS (1) & & +0.113 & +4.459 & & Surface area, $\mathrm{m}^{2}$ & 0.62 & 0.12 \\
\hline GBS (1) & & +0.155 & +21.552 & & $\begin{array}{l}\text { Head circumference, } \\
\mathrm{cm}\end{array}$ & 0.30 & 0.14 \\
\hline GBS (1) & & +0.310 & $\begin{array}{l}-4.144 \\
+\quad 0.335\end{array}$ & & $\begin{array}{l}\text { Gestational age }+ \\
\text { birth wt }\end{array}$ & 0.70 & 0.12 \\
\hline CBS (1) - gestational effect ${ }^{2}$ & & -0.398 & +0.202 & & Birth wt & 0.49 & 0.13 \\
\hline CBS (1)-wt effect ${ }^{2}$ & & +0.095 & -2.486 & & Gestational age & -0.05 & 0.12 \\
\hline GBS (1) & & -0.245 & $\begin{array}{r}+10.815 \\
+\quad 0.602 \\
-0.715\end{array}$ & & $\begin{array}{l}\text { Gestational age }+ \\
\text { birth wt+ } \\
\text { (gestation } \times w t \text { ) }\end{array}$ & 0.71 & 0.12 \\
\hline
\end{tabular}

\footnotetext{
1 Regression analyses and multiple regression analysis of relation between CBS (corrected bromide space) and various variables of maturity in intrauterine growth-retarded study infants.

${ }^{2}$ Calculations as in table II.
} 
space in the mature IGR group $(419 \mathrm{ml} / \mathrm{kg})$ was higher than any individual bromide space in the mature, NG group, save one (not shown in the figure), and was significantly in excess of the average corrected bromide space $(376 \mathrm{ml} / \mathrm{kg})$ in the $12 \mathrm{NG}$ mature neonates $(P<0.025)$ (table III).

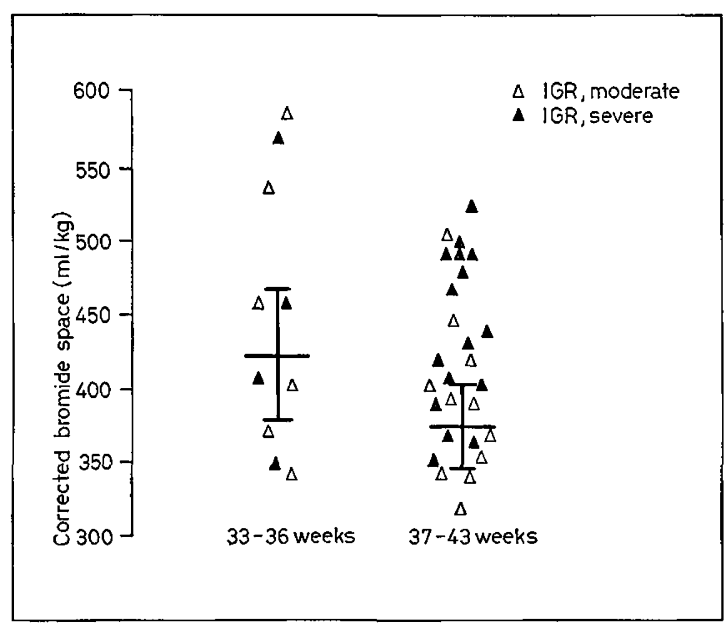

Fig.4. Corrected bromide space $(\mathrm{ml} / \mathrm{kg})$ in $10 \mathrm{imma}-$ ture and 27 mature intrauterine growth-retarded (IGR) study infants; individual data from IGR infants are superimposed on mean $\pm 1 \mathrm{SD}$ values from normally grown (NG) study infants.

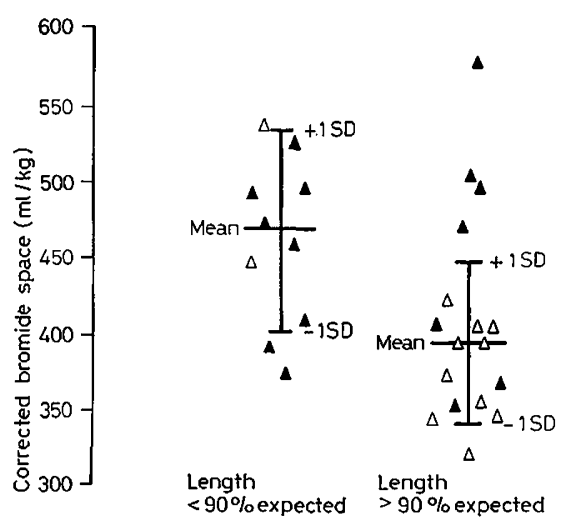

Fig. 5. Corrected bromide space $(\mathrm{ml} / \mathrm{kg})$ in 27 intrauterine growth-retarded (IGR) study infants in whom satisfactory length measurements were obtained. Individual data are grouped by severity of length retardation; group averages \pm 1 so are indicated by superimposed bars.
The data have been analyzed to determine whether variations in cause, severity, or duration of retardation in fetal growth might explain the variance evident in the scatterplots and standard errors of the IGR group. No correlation between CBS and presumed etiology of retarded fetal growth could be detected (table III). Although a tendency toward higher extracellular compartments was observed in the IGR infants exhibiting more severe weight retardation, statistically significant differences were not observed between the GBS of 'severe' and 'moderate' IGR groups.

Among the IGR infants in this study, 10 neonates demonstrated more severe length retardation than others. In figure 5 , the 27 IGR infants with satisfactory length measurements were grouped according to severity of retardation and their corrected bromide spaces compared; the differences between the two groups are apparent to inspection. In the $10 \mathrm{IGR}$ infants that exhibited the greatest length retardation the average of $468 \mathrm{ml} / \mathrm{kg}$ was the highest average CBS $/ \mathrm{kg}$ of any group studied and was significantly higher than the average value of $395 \mathrm{ml} / \mathrm{kg}$ that was shown by IGR infants with moderate length retardation $(P<0.005)$ (table III). That this observation is related to the length discrepancy and not indirectly due to the generally lower birth weights of the more length retarded IGR infants is suggested by the following: arbitrary division of the 10 IGR infants showing severe length retardation into 'small birth weight group' (5 IGR with birth weights from 1,000 to $1,660 \mathrm{~g}$ - average $1,445 \mathrm{~g}$ ) and a 'larger birth weight group' (5 IGR with birth weights from 1,760 to 2,460 g-average 2,030 g) resulted in virtually identical $\mathrm{CBS} / \mathrm{kg}$ for both groups $(470 \mathrm{ml} / \mathrm{kg}$ in the 'smaller', $467 \mathrm{ml} / \mathrm{kg}$ in the 'larger' birth weight groups).

\section{Discussion}

Extracellular space estimates in the 37 NG study infants were comparable to values reported by other authors. Expression of this data by linear relation from earlier studies $[21,26]$ has already been noted in figure 2. All previous authors of in vivo studies have, however, expressed their results as a ratio standard (percentage of body weight or $\mathrm{ml} / \mathrm{kg}$ ). In these terms, the thiocyanate space measured in four term infants [26] averaged $439 \mathrm{ml} / \mathrm{kg}$, while the bromide space (corrected for estimated intracellular chloride, Donnan equilibrium, and serum water) measured in 20 mature neonates [21] averaged $358 \mathrm{ml} / \mathrm{kg}$. The average CBS value $(376 \pm 8.4 \mathrm{ml} / \mathrm{kg})$ of mature infants in the present study was quite similar to that [21] obtained using comparable techniques and calculations. An average corrected bromide space of $378 \mathrm{ml} / \mathrm{kg}$ was 
found in the three infants of low birth weight studied within $24 \mathrm{~h}$ of birth by FINK and CHeEk [21] but these were rather large 'prematures' (2,380-2,490 $\mathrm{g}$ birth $\mathrm{wt}$ ). The higher average CBS/ $\mathrm{kg}$ of $424 \pm 7.5 \mathrm{ml} / \mathrm{kg}$ in our 24 infants of low birth weight was almost identical to that of 8 infants of low birth weight studied within $24 \mathrm{~h}$ of birth by CLAPP et al. [12] (423 ml/kg). In their study, as well as those by Smull [53] and MaLAURIN [35], data concerning both study infants and measurements were grouped in such a manner that definitive analysis was difficult, while in two other series [22, 23], infants were all studied more than $24 \mathrm{~h}$ after birth.

The present study provided in vivo evidence that confirmed the relation between increasing gestational maturity and a diminishing proportion of body mass occupied by extracellular water. Linear plot of the relation between GBS and fetal maturity shows a 'tail-off' $(r<1)$ that is progressive with increasing maturity, and expression of our data as ratio standards confirms these observations (CBS $424 \pm$ SE $7.5 \mathrm{ml} / \mathrm{kg}$ in the premature infants and $376 \pm \mathrm{sE} 8.4 \mathrm{ml} / \mathrm{kg}$ in the mature babies $[P<0.001])$. Previous studies that suggested this concept have relied on evidence from carcass analyses $[5,6,20,32]$ or have presented grouped averages of results from babies studied 1-90 days after birth [12]. Although circumstances are far from 'normal' when immature neonates are available for.study, the premature infants in this study nevertheless provided a more accurate estimate of normal fetal body composition than results obtained following intrauterine death. Restriction of study age to $24 \mathrm{~h}$ or less would also appear to minimize the effects of extrinsic influences on body composition.

The corrected bromide space of the 37 IGR infants was virtually identical with that of their weight peers when expressed in a linear manner (fig. 3). With presentation of the data as a ratio standard, however, significant differences between NG and growth-retarded neonates are apparent (fig. 4). The GBS $/ \mathrm{kg}$ exceeds the $2 \mathrm{se}$ limit for NG infants of comparable maturity in 10 of the 37 IGR infants studied. The mean CBS $/ \mathrm{kg}$ in the 27 mature IGR infants was $419_{ \pm}$se $11.3 \mathrm{ml} / \mathrm{kg}$, higher than any individual bromide space in the 13 mature, NG study infants, save one, and significantly in excess of the average CBS value $(376 \pm \mathrm{SE} 8.4 \mathrm{ml} / \mathrm{kg})$ of the NG group $(P<0.025)$. A similar trend, but not statistically significant, was observed in this study when the average CBS $/ \mathrm{kg}$ of the 10 premature IGR infants $(448 \pm \mathrm{SE} 28.3 \mathrm{ml} / \mathrm{kg})$ was compared with that of $\mathrm{NG}$ prematures $(424 \pm 7.5 \mathrm{ml} / \mathrm{kg})$. Corrected bromide spaces in excess of $476 \mathrm{ml} / \mathrm{kg}$ were observed in 11 study infants, all but one of whom were IGR infants.

Overlap of data from NG and growth-retarded study infants was largely due to the considerable hetero- geneity of results from the IGR infants as reflected by the higher standard errors in that group. Clinical differences between infants arbitrarily grouped as growth retarded may explain this scatter. In IGR infants, a trend toward higher CBS $/ \mathrm{kg}$ in the more mature or in those with severe weight retardation suggests that certain of these differences may be related to severity or duration of the in utero insult to fetal growth. Support for this speculation is found in the significant differences in CBS $/ \mathrm{kg}$ observed between the 10 IGR infants exhibiting severe length retardation $(468 \pm \mathrm{SE}$ $20.9 \mathrm{ml} / \mathrm{kg}$ ) and the other 16 IGR infants who showed less length retardation $(395 \pm$ SE $13.5 \mathrm{ml} / \mathrm{kg})(P<0.005)$.

Interpretation of these observations deserves brief comment and speculation. Previous studies in this laboratory estimating plasma volume from 10-min $\mathrm{T}-1824$ albumin space measurements in 110 neonates demonstrated an elevated mean plasma volume in IGR infants with expression of the data as percentage of body weight $(\mathrm{ml} / \mathrm{kg})$ [7]. These findings have suggested to us that a relative expansion of the extracellular compartment, similar to that seen in postnatal malnutrition, is present in situations of retarded fetal growth. The data from the present study and studies recently conducted by BIELEGKA-Winniaka [2], in which increased skin and subcutaneous tissue conductivity in undergrown neonates suggested a state of increased hydration in such infants support this hypothesis. These findings may also be explained on the basis of diminished total body fat in IGR infants, inaccurate assignment of study subjects of IGR group as a result of errors in gestational calculations, and disturbances in the primarily extracellular position of chloride as a result of retarded fetal growth. The IGR infants in this study were carefully selected and those whose mothers had anamnestic inconsistencies concerning date of last menstrual period were omitted from the study. This fact, and our observations of the clinical perinatal course and physical findings of these infants, precluded errors in assessment of gestational maturity. Although absence of intergroup differences in rate of disappearance and time at which stable bromide concentrations were achieved suggested that increased cellular permeability to halide did not factitiously alter the bromide space in IGR infants, definitive data concerning the effects of various disease states and pathologic stresses on chloride distribution are not presently available [9]. The contribution of a reduced total body fat to these results must await concurrent investigations of total body water (TBW) and extracellular water (ECW), comparisons of intracellular water-to-total body water (ICW/TBW) ratios and, more directly, examination of DNA/noncollagen nitrogen ratios in tissues of these infants and in tissues of animals with experimentally induced fetal growth re- 
tardation, studies that are currently underway in our laboratory.

The results of this study are in contrast to the predictions of extracellular deficit based on interpretations of the metabolic studies of Sinclarr et al. [49] and Sinclatr and Silverman [50]. The present study clearly demonstrated that the increased metabolic mass per kilogram body weight in undergrown neonates does not result from a loss of nonmetabolizing (extracellular) mass. An alternative explanation for the concurrence of an increased oxygen consumption per kilogram and an elevated ECW/kg may be proposed which predicts loss of nonmetabolizing ICW. Contraction of cell size due to reduction of ICW, as well as diminished total body solids are, in fact, well documented findings characteristic of postnatal malnutrition $[25,37,38,54,57,60]$. The studies of NAEYE [41-43] and CheEk [9, 10], also suggest that altera :ions in cell size, cytoplasmic volume, and cell number may take place in certain growth-retarded infants.

It should be noted that temporal discrepancies exist between the metabolic studies of SinclaIR and SILVERMAN [50] and the present investigation; their metabolic data were collected from babies 2-10 days of age, our studies of bromide dilution were carried out within $24 \mathrm{~h}$ of birth. Redistribution or excessive loss of fluid from an extracellular location may reconcile these findings. The literature provides conflicting and inadequate data concerning the early adjustments of extracellular fluid in the perinate $[8,21,35]$. Although unusual loss of ECW would appear unlikely, definitive data on this point are not yet available.

Of final interest is the coexistence of a reduced cell number, an increased metabolic rate per kilogram, a diminished total body weight, and an increased proportion of body weight occupied by ECW that may be explained on the basis of an altered cellular metabolic rate (increased oxygen consumption per cell) in growthretarded infants. A similar analogy exists in the data of MONTGOMERY [39] which show that the normal or reduced metabolic rate per kilogram present in postnatal malnutrition rises in a striking manner during the recovery or reparitive phase of the disorder. Concurrent and serial studies of metabolic and fluid compartments, essential to evalute this question, are currently under consideration by SincLaIR [51].

\section{Summary}

Clinical, metabolic, and developmental observations clearly separate one group of infants of low birth weight, small by virtue of retarded intrauterine growth, from a second group of neonates whose small size is related to early or 'premature' birth. Although a variety of causes and associations have been related to this syndrome, many of the anatomic and physiologic findings in these fetal growth-retarded neonates resemble the changes observed in postnatal proteincalorie malnutrition. The present study reports measurements of the corrected bromide space in 37 growthretarded and 37 normally grown, vaginally delivered neonates studied within $24 \mathrm{~h}$ of birth. The corrected bromide space of the growth-retarded infants was virtually identical with that of their weight peers, there being no significant difference in the regression of CBS versus birth weight between the two groups. The average CBS $/ \mathrm{kg}$ in the growth retardates was, however, significantly higher than the mean for their gestational maturity peers, a finding compatible with recent studies from our laboratory demonstrating an expanded plasma volume per kilogram in fetal growth retardation. These findings, similar to the body water alterations that accompany malnutrition, demonstrate another point of similarity between retarded intrauterine growth and protein-calorie malnutrition.

\section{References and Notes}

1. Allexne, G.A.O.: Studies on total body potassium in infantile malnutrition: the relation to body fluid spaces and urinary creatinine. Glin. Sci. 34: 199 (1968).

2. Bielecka-Winnicka, A.: Hydration in tissues of newborns with too-low weight at birth. Ann. paediat. 207: 125 (1966).

3. Boyd, E.: The growth of the surface area of the human body (University of Minnesota Press, Minneapolis 1935).

4. Brinkman, G. L.; Bowie, M.D.; Friss-Hansen, B. and Hansen, J.D.: Body water composition in kwashiorkor before and after loss of edema. Pediatrics 36: 94 (1965).

5. Camerer, W., Jr.: Die chemische Zusammensetzung des Neugeborenen. Z. Biol. 39: 173 (1900).

6. Camerer, W., Jr.: Die chemische Zusammensetzung des neugeborenen Menschen. Z. Biol. 43: 1 (1902).

7. CAssady, G.: Plasma volume studies in low birth weight infants. Pediatrics 38: 1020 (1966).

8. CHEEK, D.B.: Extracellular volume: its structure and measurement and the influence of age and disease. J.Pediat. 58: 103 (1961).

9. CheEK, D. B.: Human growth: Body composition, cell growth, energy and intelligence (Lea and Febiger, Philadelphia 1968).

10. Cheek, D.B.; Graystone, J. and Mehrizi, A.: The importance of muscle cell number in children 
with congenital heart disease. Bull.Johns Hopk. Hosp. 118: 140 (1966).

11. Gheek, D.B.; West, C.D. and Golden, C.C.: The distribution of sodium and chloride and the extracellular fluid volume in the rat. J. clin. Invest. 37: 340 (1957).

12. Clapp, W.M.; Butterfield, L.J. and O'Brien, D.: Body water compartments in the premature infant, with special reference to the effects of the respiratory distress syndrome and of maternal diabetes and toxemia. Pediatrics 29: 883 (1962).

13. Gokington, L.; Hanna, F. M. and JAGkson, R. L.: Changes in body composition of malnourished infants during repletion. Ann. N.Y. Acad. Sci. 110: 849 (1963).

14. Cornblath, M.; Odell, G.B. and Levin, E.Y.: Symptomatic neonatal hypoglycemia associated with toxemia of pregnancy. J.Pediat. 55: 545 (1959).

15. CROxTon, F.E.: Elementary statistics with applications in medicine and the biological sciences (Dover Publications, New York 1953).

16. DeAn, R.F.A.: Some effects of malnutrition on body composition; in: J.BROzEk: Human body composition: Approaches and applications, vol.7, Symp. soc. study of human biology, p. 267 (Pergamon Press, Oxford 1965).

17. Dreyfus-Brisac, G. ; Flescher, J. et Plassart, E.: L'électroencéphalogramme: Critère d'âge conceptionnel du nouveau-né à terme et prématuré. Biol.neonat. 4: 154 (1962).

18. Drillene, G. M.: Personal communication.

19. Elkinton, J.R. and Wrodowson, E. M. : Effect of chronic undernutrition on body composition in the rat. Metabolism 8: 404 (1959).

20. FeE, B. A. and WeIr, W. B., Jr.: Body composition of infants of diabetic mothers by direct analysis. Ann. N.Y.Acad. Sci. 110: 869 (1963).

21. Fink, G.W. and Cheek, D.B.: The corrected bromide space (extracellular volume) in the newborn. Pediatrics 26: 397 (1960).

22. Finley, S. C. and Hare, R.S.: Bromide space in infants and children. Amer. med. Ass. J. Dis. Child. 98: 749 (1959).

23. Flexner, L.B.; Wilde, W.S.; Proctor, N.K.; Cowie, D.B.; Vosburgh, G.J. and Hellman, L.M.: The estimation of extracellular and total body water in the newborn human infant with radioactive sodium and deuterium oxide. J. Pediat. 30: 413 (1947).

24. Forbes, G.B.; Feid, A.F.; Bondurant, J. and Etheridge, J.: Changes in total body chloride during growth. Pediatrics 17: 334 (1956).

25. Frenk, S.; Metcoff, J.; Gomez, F.; RamosGalvan, R.; Cravioto, J. and Antonwicz, I.:
Intracellular composition and homeostatic mechanism in severe chronic infantile malnutrition. II. Composition of tissues. Pediatrics 20: 105 (1957).

26. Fris-HANSEN, B.: Cihanges in body water compartments during growth. Acta paediat. scand. 46: Suppl. 110 (1957).

27. Garrow, J.S.; Fletcher, K. and Halliday, D.: Body composition in severe infantile malnutrition. J. clin. Invest. 44: 417 (1965).

28. GRuenwald, P.: Infants of low birth weight among 5000 deliveries. Pediatrics 34: 157 (1964).

29. Gruenwald, P.: Growth of the human fetus. I. Normal growth and its variation. Amer.J. Obstet. Gynec. 94: 1112 (1966).

30. Hansen, J. D.; Brinkman, G.L. and Bowre, M.D. : Body composition in protein-calorie malnutrition. Sth. Afr. Med.J. 39: 491 (1965).

31. Huxlex, J.S.: Problems of relative growth (The Dial Press, New York 1932).

32. Iob, V. and Swanson, W.W.: Mineral growth of the human fetus. Amer. J. Dis. Child. 47: 302 (1934).

33. KERPEL-FroniUs, E.: Volume and composition of the body fluid compartments in severe infantile malnutrition. J. Pediat. 56: 826 (1960).

34. Kerpel-Fronius, E. and Kovach, S.: The volume of extracellular body fluids in malnutrition. Pediatrics 2: 21 (1948).

35. MaLaurin, J. C. : Changes in body water distribution during the first two weeks of life. Arch. Dis. Childh. 41: 286 (1966).

36. Mendes, C.B. and Waterlow, J.C.: The effect of a low protein diet, and of refeeding, on the composition of liver and muscle in the weanling rat. Brit.J. Nutr. 12: 74 (1958).

37. Metcoff, J.: Biochemical effects of protein-calorie malnutrition in man. Ann. Rev.Med. 18: 377 (1967).

38. Metcoff, J.; Frenk, S.; Gordillo, G.; Gomez, F.; Ramos-Galvan, R.; Gravioto, J.; Janeway, G. A. and GAmBLE, J. L.: Intracellular composition and homeostatic mechanisms in severe chronic infantile malnutrition. IV. Development and repair of the biochemical lesion. Pediatrics 20: 317 (1957).

39. Montgomery, R. D.: Changes in the basal metabolic rate of the malnourished infant and their relation to body composition. J. clin. Invest. 41: 1653 (1962).

40. Montgomery, R.D.: Muscle morphology in infantile protein malnutrition. J.clin. Path. 15: 511 (1962).

41. NAeye, R.L.: Cardiovascular abnormalities in infants malnourished before birth. Biol.neonat. 8: 104 (1965). 
42. NAEYE, R.L.: Malnutrition: probable cause of fetal growth retardation. Arch. Path. 79: 284(1965).

43. NAEYE, R. L.: Abnormalities in infants of mothers with toxemia of pregnancy. Amer. J. Obstet. Gynec. 95: 276 (1966).

44. Neligan, G.A.; Robson, E. and Watson, J.: Hypoglycaemia in the newborn: a sequel of intrauterine malnutrition. Lancet $i$ : 1282 (1963).

45. Schnieden, H.; Hendrickse, R.G. and Haigh, C. P.: Studies in water metabolism in clinical and experimental malnutrition. Trans.roy. Soc.trop. Med. Hyg. 52: 169 (1958).

46. Scott, K. E. and Usher, R.: Epiphyseal development in fetal malnutrition syndrome. New Engl.J. Med. 270: 822 (1964).

47. Scott, K.E. and Usher, R.: Fetal malnutrition: its incidence, causes and effects. Amer.J. Obstet. Gynec. 94: 951 (1966).

48. Silverman, W.A. and Sinclair, J. C.: Infants of low birth weight. New Engl.J.Med. 274: 448 (1966).

49. Sinclair, J. C. ; Scopes, J.W. and Silverman, W.A.: Metabolic reference standards for the neonate. Pediatrics 39: 724 (1967).

50. Sinclair, J. C. and Silverman, W. A.: Intrauterine growth in active tissue mass of the human fetus, with particular reference to the undergrown baby. Pediatrics 38: 48 (1966).

51. Sinclatr, J. G.: Personal communication.

52. Sмiтн, R.: Total body water in malnourished infants. Clin. Sci. 19: 475 (1960).

53. Smulc, N.W.: Total body water and bromide space determinations in premature infants. (Abstract) Amer.J. Dis. Child. 96: 494 (1958).

54. Thomson, R.Y.; Heagy, F. C.; Hutchinson, W. C. and Davinson, J.N.: The deoxyribonucleic acid content of the rat cell nucleus and its use in expressing the results of tissue analysis, with particular reference to the composition of liver tissue. Biochem.J. 53: 460 (1953).
55. VAN Den Berg, B.J. and Yerushalmy, J.: The relationship of the rates of intrauterine growth of infants of low birth weight to mortality, morbidity and congenital anomalies. J. Pediat. 69: 531 (1966).

56. Waterlow, J. C. and Mendes, C. B.: Composition of muscle in malnourished human infants. Nature, Lond. 180: 1361 (1957).

57. Waterlow, J. C. and Weisz, T.: The fat, protein and nucleic acid content of the liver in malnourished human infants. J.clin. Invest. 35: 346 (1956).

58. WeIl, W.B., Jr.: Chemical composition of the fetus; in: H.L.Barnett: Pediatrics, 14th ed., p. 21 (Appleton-Century-Crofts, New York 1968).

59. WrdDowson, E.M.; Drckerson, J.W.T. and MaCANCE, R.A.: Severe undernutrition in growing and adult animals. IV. The impact of severe undernutrition on the chemical composition of the soft tissues of the pig. Brit.J.Nutr. 14: 457 (1960).

60. Winick, M. and Noble, A.: Cellular response in rats during malnutrition at various ages. J.Nutr. 89: 300 (1966).

61. Wolf, R.L. and Eadie, G.S.: Reabsorption of bromide by the kidney. Amer.J. Physiol. 163: 436 (1939).

62. Without the invaluable technical assistance of Rachel Milstead, this work would not have been possible. To her, the pediatric housestaff and B.J. STALLINGS, the author acknowledges his grateful appreciation.

63. Supported by Public Health Service Research Grant no. R01 HD 02697 from the National Institute of Child Health and Human Development, National Institues of Health.

64. Requests for reprints should be addressed to: George Gassady, M.D., Director of Newborn Division and Newborn Nurseries, University of Alabama Medical Center, 1919 Seventh Avenue South, Birmingham, AL 35233, USA.

65. Accepted for publication August 20, 1969. 